\title{
The development and testing of a computerised temperature control system in conventional electric ovens
}

\author{
DL Viljoen, M Muller, JB de Swardt, A Sadie \& MC Vosloo
}

\section{OPSOMMING}

Die doel van die studie was om 'n kontrolestelsel te ontwikkel wat die gemiddelde oondtemperatuur van twee konvensionele elektriese oonde beheer, en om te bepaal of die kontrolestelsel tussen en binne oonde vergelykbare en herhaalbare resultate lewer betreffende gemiddelde oondtemperatuur en die kleur, vogverlies, hoogte en tekstuur van kleinkoekies en laagkoeke soos bepaal deur objektiewe meetinstrumente. Geen betekenisvolle verskil is gevind tussen en binne behandelings wat die gemiddelde oondtemperatuur en die meeste produkeienskappe betref nie.

Hierdie beheerstelsel kan dus vir voedselnavorsing aanbeveel word. Dit verbeter temperatuurbeheer binne en tussen konvensionele elektriese oonde en kan ' $n$ sinvolle bydrae tot eksperimentering in voedselnavorsing lewer waar konstantheid tydens die herhaling van behandelings van kardinale belang vir betroubare resultate is.

\section{—Ms DL Viljoen, Ms M Muller \& Dr MC Vosloo} Department of Consumer Studies, University of Stellenbosch

\section{- Dr JB de Swardt}

Department of Electrical and Electronic Engineering, University of Stellenbosch

\section{- Ms A Sadie}

Department of Genetics, University of Stellenbosch

The authors wish to acknowledge the cooperation and assistance of Defy Appliances Ltd, Durban.

\section{INTRODUCTION}

In food research, where the quality of food is investigated during heating, temperature variation is one of the variables that must be controlled at all times. Significant variability in heat and mass transfer leads to error in the research process and must therefore be limited (Fahloul et al, 1994). A reliable research instrument, which could eliminate the factors that are known to produce variability, is vital in food research (Kilborn \& Tipples, 1981; Swain et al, 1997:326-329).

Conventional electric ovens are often used for food research purposes at research laboratories (Garrison \& Peart, 1986). Conventional electric ovens usually have capillary thermostats and consequently a large variation in average oven temperature, and long heating and cooling cycles. Standard specifications for conventional electric ovens require the average internal temperature at each thermostat setting not to differ from the temperature indicated on the thermostat by more than $10^{\circ} \mathrm{C}$ (SABS, 1997). In ovens with a variation in average oven temperature of $10^{\circ} \mathrm{C}$, the average length of the cooling and heating cycle is approximately $5 \mathrm{~min}$ (Muller, 1992). The latter variation in average oven temperature and time for the heating and cooling cycles is very crude and there could be a significant percentage variation with replication of treatments.

Some researchers have attempted to control conditions during baking by using ovens they designed and built themselves (Peart et al, 1980; Maris et al, 1995). A study by Viljoen et al (1995) determined whether an electronic temperature controller (ETC) - an electronic apparatus with a solid-state switch and sensitive sensor - could provide improved temperature control and consequently sustained food quality compared to a capillary thermostat in a conventional electric oven. It was found that with replication of treatments there was significantly $(p \quad 0,05)$ greater variation in moisture loss and Hunter L-values in cakes when the ETC was not used. Without the ETC, moisture losses ranged between $65,6 \mathrm{~g}$ and $75,5 \mathrm{~g}$, i.e. a range of 9,9 . Cakes baked with the ETC showed moisture losses between 67,1 and $70,0 \mathrm{~g}$. With the ETC the range was therefore 2,9. The Hunter L-values of cakes baked without the ETC ranged between 39,38 and 41,77 and with the ETC between 39,95 and 41,02 . Although the ETC significantly increased the constancy of selected measurements with replication of treatments, it was recommended that the mains voltage be monitored and the system be computerised to record the data automati- 
cally. Both these aspects would enhance the temperature control capability of the ETC and consequently the reliability of research data.

In the light of the limitations of temperature control in conventional electric ovens and the fact that conventional electric ovens are often used in consumeroriented food research, an efficient computerised electronic temperature control system had to be developed to provide improved temperature control in conventional electric ovens and consequently an increased constancy of measurements within and between ovens. This could in turn improve the reliability of research findings. Ovens with similar heat and mass transfer capabilities are essential for use during product development and research on products that are ultimately prepared in conventional electric ovens (Kilborn \& Tipples, 1981).

The aim of the study was to determine whether a computerised temperature control system (CTCS) in two similar conventional electric ovens (Oven A and Oven B) with and without products, would firstly produce comparable results, to be determined by instrumental measurements, with regard to time/temperature measurements and product quality characteristics in shortbread-type biscuits and cakes, and secondly effectively improve the constancy of measurements with replication of treatments. A further aim was to determine the significance of temperature control to within $1^{\circ} \mathrm{C}$ and to establish whether a relationship exists between an increase of $1^{\circ} \mathrm{C}$ in the set oven temperature and its effect on the quality characteristics of baked products.

\section{MATERIALS AND METHODS}

\section{Apparatus}

The CTCS was specifically designed and built for this study. To ensure uniformity, two conventional electric stoves (Defy 831) with nonwelded plates were assembled and packed with insulating material of exactly the same mass by a single employee. The amperage of the bake elements on the floor of the oven cavity was also identical $(10,6 \mathrm{~A})$. The top elements $(1,2 \mathrm{~A})$ in the roof of the oven cavity operate simultaneously with the bake elements during the baking process.

The ovens were connected to the same mains phase to ensure equal power. The capillary thermostats were replaced with thermocouples to enable the computer to record measurements. K-type $\mathrm{Ni}-\mathrm{Cr} / \mathrm{Ni}-\mathrm{Al}$ (standard) thermocouples with a temperature range of $0-1100^{\circ} \mathrm{C}$ and a diameter of $1,6 \mathrm{~mm}$ were installed through small openings in either side of each oven. The eight thermocouples in each oven, four on each side, were positioned $50 \mathrm{~mm}$ from the sides of the oven casing on the same plane as the middle shelf. This allows for large square or rectangular baking sheets to be placed in the centre of the oven without the thermocouples being too near the sides of the oven casing. The thermocouples were connected to an interface unit with a reference temperature sensor.
The control system, a discrete proportional-plusintegrator $(\mathrm{PI})$ controller, consisted of the computer, control algorithm and a 16-channel thermocouple card (Dorf, 1986:469-470). The PI controller was modelled as a first-order system with delay and its design was based on the characteristics of the system from a cold temperature. The system runs on the computer disc operating system (DOS) and efficiently compensates for fluctuations in mains power supply. The system allows for both ovens to be used simultaneously or either oven to be used individually. The entire CTCS was symmetrically positioned with regard to placement of the various components of the system as well as the length of wires between components.

As the delay time of the oven was 20 s (i.e. the delay from the time the signal is received until the controller acts), the average oven temperature was calculated every $20 \mathrm{~s}$ and the elements of the oven, regulated by a control signal, switched on and off according to this average. The control signal, which indicates functioning capacity with regard to total amount of power used, ranged between zero and one and regulated the average oven temperature in each oven. Figure 1 illustrates that without products the CTCS regulates the average oven temperature to within $1^{\circ} \mathrm{C}$ of the set temperature and that the calculated average oven temperature is $200,0^{\circ} \mathrm{C}$ for Oven $\mathrm{A}$ and $200,0^{\circ} \mathrm{C}$ for Oven $\mathrm{B}$. Figure 2 illustrates the decrease in average oven temperature after the oven door is opened and the product is placed in the oven, as well as the subsequent rise and stabilisation of the average oven temperature. After $24 \mathrm{~min}$ the calculated average oven temperature is $198,8^{\circ} \mathrm{C}$ for Oven $\mathrm{A}$ and $198,6^{\circ} \mathrm{C}$ for Oven B.

The PI-controller-user interface displays the logged values visually. The data from Oven A and Oven B were split so that they could easily be distinguished from one another. The average oven temperature, average control values and average temperatures of thermocouples were registered and displayed at $2 \mathrm{~s}$ intervals.

The ovens are housed in an air-conditioned laboratory to maintain an ambient room temperature of $19^{\circ} \mathrm{C}$ for the duration of all experiments. When the ovens are heated from ambient temperature, it takes a considerable period of time to stabilise, i.e. to maintain the average oven temperature at $0,5^{\circ} \mathrm{C}$ on either side of the set temperature. The system was therefore adapted to indicate that the ovens had stabilised for $10 \mathrm{~min}$ at $0,5^{\circ}$ $\mathrm{C}$ on either side of the set temperature and were ready for use. A magnetic door switch with a time indicator was also installed and monitored by computer to signal every $4 \mathrm{~s}$ once the oven door was opened. This enabled the researcher to control the period of time that the oven door was open and the resultant decrease in oven temperature and recovery of the oven temperature to the set temperature. A period of $4 \mathrm{~s}$ was specifically chosen for this study. Other studies could require shorter or longer periods for opening the oven door and the computer merely has to be preset accordingly. 
FIGURE 1: $\quad$ TEMPERATURE PROFILES OF OVEN A AND OVEN B WITHOUT PRODUCTS 
FIGURE 2: $\quad$ TEMPERATURE PROFILES OF OVEN A AND OVEN B WITH PRODUCTS AT $200^{\circ} \mathrm{C}$ FOR 24 MIN

The development and testing of a computerised temperature control system in conventional electric ovens 


\section{Experimental layout}

The efficiency of the CTCS was tested with biscuits and cakes. These two products differ considerably in terms of moisture content, leavening agents, baking time and temperature, and both products are considered good indicators of oven performance (Garrison \& Peart, 1986; Baker et al, 1990; Shelke et al, 1990; De Vries et al, 1994). Tests were conducted without products in the oven cavity in order to draw comparisons between these and tests with products in the oven. The treatment design for the tests with and without products was a $2 \times 4$ factorial design. The factors were two ovens (Oven A and Oven B) and four temperature settings (each $1^{\circ} \mathrm{C}$ apart). The treatments for biscuits and cakes were replicated six times. The treatments without the products in the ovens were replicated four times.

Baking procedure for biscuits The ingredients for the biscuits are listed in Table 1. The margarine was creamed using the K-attachment of the Hobart Mixer for $2 \mathrm{~min}$ at speed setting 3 (591 rpm). The sugar was creamed with the margarine for $6 \mathrm{~min}$ at speed setting 3 . The cornflour was sifted into the creamed mixture and beaten at speed setting 1 (139 rpm). The cake flour was sifted into the bowl and beaten for $1 \mathrm{~min}$ at speed setting 1 and a further 1 min at speed setting 3 . The dough was cooled for approximately $5 \mathrm{~min}$ to an internal temperature of $17-18^{\circ} \mathrm{C}$. Three rows of six biscuits each were pressed out with a Marcado biscuit press, directly onto two baking sheets. One baking sheet was placed in the centre of each oven. The biscuits were baked for $12 \mathrm{~min}$ at 189, 190, 191 and $192^{\circ}$ $\mathrm{C}$. The biscuits were allowed to cool for $1 \mathrm{~h}$ and were then placed in plastic bags in rigid airtight containers and frozen at $-21^{\circ} \mathrm{C}$.

Baking procedure for cakes The ingredients for cakes are listed in Table 1. The egg and milk were beaten together for $1 \mathrm{~min}$ with an electric hand beater and added to the cake mix. The cake mix and fluid were beaten using a Hobart mixer, first for $1 \mathrm{~min}$ at speed setting 1 (139 rpm) and then for 2 min at speed setting 2 (285 rpm). Cake batter $(450 \mathrm{~g})$ was placed in each of the two cake pans (200 $\mathrm{mm}$ in diameter) and one pan was placed in the centre of each oven. The cakes were baked for $24 \mathrm{~min}$ at 199, 200, 201 and $202^{\circ} \mathrm{C}$. The cakes were allowed to cool for 1 and were then placed in rigid airtight containers and frozen at $21^{\circ} \mathrm{C}$.

\section{Measurements}

After frozen storage for approximately seven days the products were defrosted at $19^{\circ} \mathrm{C}$ for $1 \mathrm{~h}$ and subjected to the following measurements:

Time/temperature The average oven temperature for each replication with and without products was calculated from the registered data.

Moisture loss The Moisture loss of the biscuits and cakes after baking was determined by subtracting the mass $(\mathrm{g})$ of the product immediately after removal from the oven from the initial mass of the raw product before baking. The percentage moisture loss of the biscuits was calculated according to AACC Method 44-01 (AACC, 1983).

Height of cakes The layer cake measuring template was used to determine the height, i.e. index to volume of the cakes, using the AACC Method 10-91 (AACC, 1983).

Colour One measurement, using a Gardner Colorgard colorimeter, was taken on the underside of every biscuit baked during each treatment in Oven $A$ and Oven B (three rows of six biscuits). This provided a representative sample for instrumental colour measurement. Blisters on the underside of the biscuits could have an influence on colour measurements and therefore all the biscuits in a particular batch were subjected to instrumental colour measurement (Little \& Mackinney, 1969). Hunter L-values were determined (Pomeranz \& Meloan, 1987).

The upper crust of the cake samples from each treatment in each oven was subjected to instrumental colour measurement. Eight cylindrical samples were randomly extracted from each cake, using a cutter with a $50 \mathrm{~mm}$ diameter, to obtain a representative sample. Hunter L-values were determined (Pomeranz \& Meloan, 1987).

Texture The biscuit samples were tested for compression with the Stable Micro Systems texture analyser. Eighteen biscuits from every replication were subjected to a puncture test with a stainless steel needle probe, $1,5 \mathrm{~mm}$ in diameter, at a rate of 0,8 $\mathrm{mm} / \mathrm{s}$. The maximum force to puncture each biscuit to a depth of $3 \mathrm{~mm}$ from the upper surface was measured. The mean force $(\mathrm{N})$ required to puncture the samples was used in the analysis of the data (Bourne, 1982:136-141). According to the literature, it is recommended that each biscuit be punctured at least 12 13 times as more variation exists within a single biscuit than between biscuits (Baltsavias et al, 1997). During preliminary tests it was found that 18 biscuits did not provide a significantly different result from a representative sample of 12 biscuits, each of which was punctured 13 times.

The texture of the cakes was determined by using a Stable Micro Systems texture analyser. The maximum number of samples, i.e. eight cylindrical samples (circular plugs) was used to ensure a representative sample. The cake samples were $50 \mathrm{~mm}$ in diameter and the top section containing the surface crust of each sample was removed $20 \mathrm{~mm}$ from the bottom crust of the cake with a sharp knife while positioned in a rigid metal template $20 \mathrm{~mm}$ high. Each cake sample was compressed $5 \mathrm{~mm}$ with a $75 \mathrm{~mm}$ aluminium compression platen at a rate of $1,6 \mathrm{~mm} / \mathrm{s}$, i.e. $25 \%$ compression. The force $(\mathrm{N})$ required to compress the sample $5 \mathrm{~mm}$ was thus measured (Sobczynska \& Setser, 1991). 
TABLE 1: $\quad$ FORMULATION OF BISCUITS AND CAKES

\begin{tabular}{|l|c|l|c|}
\hline \multicolumn{2}{|c|}{ Biscuits } & \multicolumn{2}{c|}{ Cakes } \\
\hline \multicolumn{1}{|c|}{ Ingredients } & Quantity (g) & \multicolumn{1}{c|}{ Qngredients } & 600 \\
\hline Margarine (block) & 250 & Moir's Vanilla Cake Mix & 150 \\
\hline Castor sugar & 125 & Whole fresh egg & 300 \\
\hline Corn flour & 125 & Milk (low fat) & \\
\hline Cake flour & 250 & & \\
\hline
\end{tabular}

TABLE 2:

MEANS FOR AVERAGE OVEN TEMPERATURE WITHOUT PRODUCTS (2 OVENS X 4 TEMPERATURES) AND WITH BISCUITS (2 OVENS X 4 TEMPERATURES)

\begin{tabular}{|c|c|c|c|c|}
\hline Set oven temperature $\left({ }^{\circ} \mathrm{C}\right)$ & \multicolumn{2}{|c|}{ Means for average oven temperature $\left({ }^{\circ} \mathrm{C}\right)$} & & \\
\hline & Without products ${ }^{1}$ & With products ${ }^{2}$ & & \\
\hline & Oven A & Oven B & Oven A & Oven B \\
\hline 189 & $188,99 \mathrm{a}$ & $188,98 \mathrm{a}$ & $186,73 \mathrm{a}$ & $186,92 \mathrm{ab}$ \\
\hline 190 & $190,00 \mathrm{~b}$ & $189,99 \mathrm{~b}$ & $187,46 \mathrm{bc}$ & $187,94 \mathrm{~cd}$ \\
\hline 191 & $190,99 \mathrm{c}$ & $190,99 \mathrm{c}$ & $188,37 \mathrm{~d}$ & $188,44 \mathrm{~d}$ \\
\hline 192 & $191,99 \mathrm{~d}$ & $192,00 \mathrm{~d}$ & $189,50 \mathrm{e}$ & $189,61 \mathrm{e}$ \\
\hline
\end{tabular}

1. Without products: Means with different letters in the same row or same column differ significantly at the $5 \%$ level of significance (LSD at 0

2. With products: Means with different letters in the same row or same column differ significantly at the $5 \%$ level of significance (LSD at 0,05: 0,69)

TABLE 3: $\quad$ MEANS FOR AVERAGE OVEN TEMPERATURE WITHOUT PRODUCTS (2 OVENS X 4 TEMPERATURES) AND WITH CAKES (2 OVENS X 4 TEMPERATURES)

\begin{tabular}{|c|c|c|c|c|}
\hline Set oven temperature $\left({ }^{\circ} \mathbf{C}\right)$ & \multicolumn{3}{|c|}{ Means for average oven temperature $\left({ }^{\circ} \mathbf{C}\right)$} \\
\cline { 2 - 5 } & \multicolumn{2}{|c|}{ Without products $^{1}$} & \multicolumn{2}{c|}{ With products $^{2}$} \\
\cline { 2 - 5 } & Oven A & Oven B & Oven A & Oven B \\
\hline 199 & $199,00 \mathrm{a}$ & $198,99 \mathrm{a}$ & $197,95 \mathrm{a}$ & $198,11 \mathrm{a}$ \\
\hline 200 & $199,99 \mathrm{~b}$ & $199,99 \mathrm{~b}$ & $198,78 \mathrm{bc}$ & $198,86 \mathrm{bc}$ \\
\hline 201 & $200,99 \mathrm{c}$ & $200,99 \mathrm{c}$ & $199,68 \mathrm{~d}$ & $199,65 \mathrm{~d}$ \\
\hline 202 & $201,98 \mathrm{~d}$ & $201,98 \mathrm{~d}$ & $200,56 \mathrm{e}$ & $200,56 \mathrm{e}$ \\
\hline
\end{tabular}

1 Without products: Means with different letters in the same row or same column differ significantly at the $5 \%$ level of significance (LSD at 0,05: 0,29)

2 With products: Means with different letters in the same row or same column differ significantly at the $5 \%$ level of significance (LSD at 0,05: 0,48)

TABLE 4:

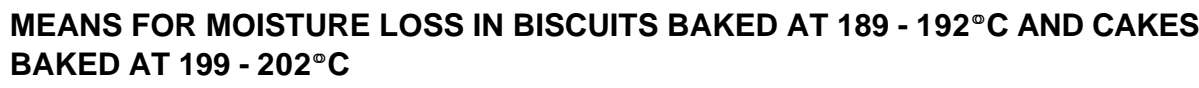

\begin{tabular}{|c|c|c|c|c|}
\hline \multirow[t]{3}{*}{ Set oven temperature $\left({ }^{\circ} \mathrm{C}\right)$} & \multicolumn{4}{|c|}{ Means for moisture loss } \\
\hline & \multicolumn{2}{|c|}{ Moisture loss (\%) in biscuits } & \multicolumn{2}{|c|}{ Moisture loss $(\mathrm{g})$ in cakes $^{2}$} \\
\hline & Oven A & Oven B & Oven A & Oven B \\
\hline $189^{3} / 199^{4}$ & $9,52 \mathrm{a}$ & $9,45 \mathrm{a}$ & $32,60 \mathrm{a}$ & $33,55 \mathrm{bc}$ \\
\hline $190^{3} / 200^{4}$ & $9,75 \mathrm{a}$ & $9,86 a$ & $32,75 \mathrm{a}$ & $33,13 a b$ \\
\hline $191^{3} / 201^{4}$ & $9,68 \mathrm{a}$ & $9,88 \mathrm{a}$ & $33,21 \mathrm{ab}$ & $34,41 \mathrm{de}$ \\
\hline $192^{3} / 202^{4}$ & $9,70 \mathrm{a}$ & $9,75 a$ & $33,90 \mathrm{~cd}$ & $34,61 \mathrm{e}$ \\
\hline
\end{tabular}

1. Moisture loss in biscuits: Means with different letters in the same row or same column differ significantly at the $5 \%$ level of significance (LSD at 0,05: 0,48)

2 Moisture loss in cakes: Means with different letters in the same row or same column differ significantly at the $5 \%$ level of significance (LSD at 0,05: 0,63)

3 Set oven temperature for biscuits

4 Set oven temperature for cakes 
FIGURE 3: REGRESSION OF AVERAGE OVEN TEMPERATURE AT SET OVEN TEMPERATURE FOR BISCUITS BAKED AT $189-192^{\circ} \mathrm{C}$

The development and testing of a computerised temperature control system in conventional electric ovens 
FIGURE 4: REGRESSION OF AVERAGE OVEN TEMPERATURE AT SET OVEN TEMPERATURE FOR CAKES BAKED AT $199-202^{\circ} \mathrm{C}$ 
FIGURE 5: REGRESSION OF MOISTURE LOSS AT SET OVEN TEMPERATURE FOR CAKES BAKED AT $199-202^{\circ} \mathrm{C}$

The development and testing of a computerised temperature control system in conventional electric ovens 
TABLE 5: $\quad$ VARIATION WITHIN TREATMENTS OF MOISTURE LOSS IN BISCUITS AND CAKES

\begin{tabular}{|c|c|c|c|c|}
\hline & \multirow{2}{*}{\multicolumn{2}{|c|}{$\begin{array}{c}\text { Variation in moisture loss within treatments } \\
(\%) \\
\text { Biscuits baked at } 190^{\circ} \mathrm{C} \text { for } 12 \mathrm{~min}\end{array}$}} & \multirow{2}{*}{\multicolumn{2}{|c|}{$\begin{array}{c}\text { Variation in moisture loss within treatments } \\
(\mathrm{g}) \\
\text { Cakes baked at } 200^{\circ} \mathrm{C} \text { for } 24 \text { min }\end{array}$}} \\
\hline & & & & \\
\hline & Oven A & Oven B & Oven A & Oven B \\
\hline Rep 1 & 10,09 & 10,09 & 31,90 & 32,70 \\
\hline Rep 2 & 9,88 & 10,00 & 32,70 & 33,10 \\
\hline Rep 3 & 9,70 & 9,85 & 32,90 & 33,60 \\
\hline Rep 4 & 9,47 & 9,64 & 32,80 & 32,60 \\
\hline Rep 5 & 9,70 & 9,90 & 33,50 & 33,60 \\
\hline Rep 6 & 9,70 & 9,71 & 32,70 & 33,20 \\
\hline $\begin{array}{c}\text { Mean } \pm \\
\text { standard error }\end{array}$ & $\begin{array}{l}9,75 \pm \\
0,0852\end{array}$ & $\begin{array}{l}9,86 \pm \\
0,0695\end{array}$ & $\begin{array}{l}32,75 \pm \\
0,2093\end{array}$ & $\begin{array}{l}33,13 \pm \\
0,1744\end{array}$ \\
\hline $\begin{array}{l}\text { Probability of } \\
\text { equal vari- } \\
\text { ances }(P)\end{array}$ & \multicolumn{2}{|c|}{0,6647} & \multicolumn{2}{|c|}{0,6989} \\
\hline
\end{tabular}

TABLE 6: $\quad$ VARIATION WITHIN TREATMENTS OF HUNTER L-VALUES IN BISCUITS AND CAKES

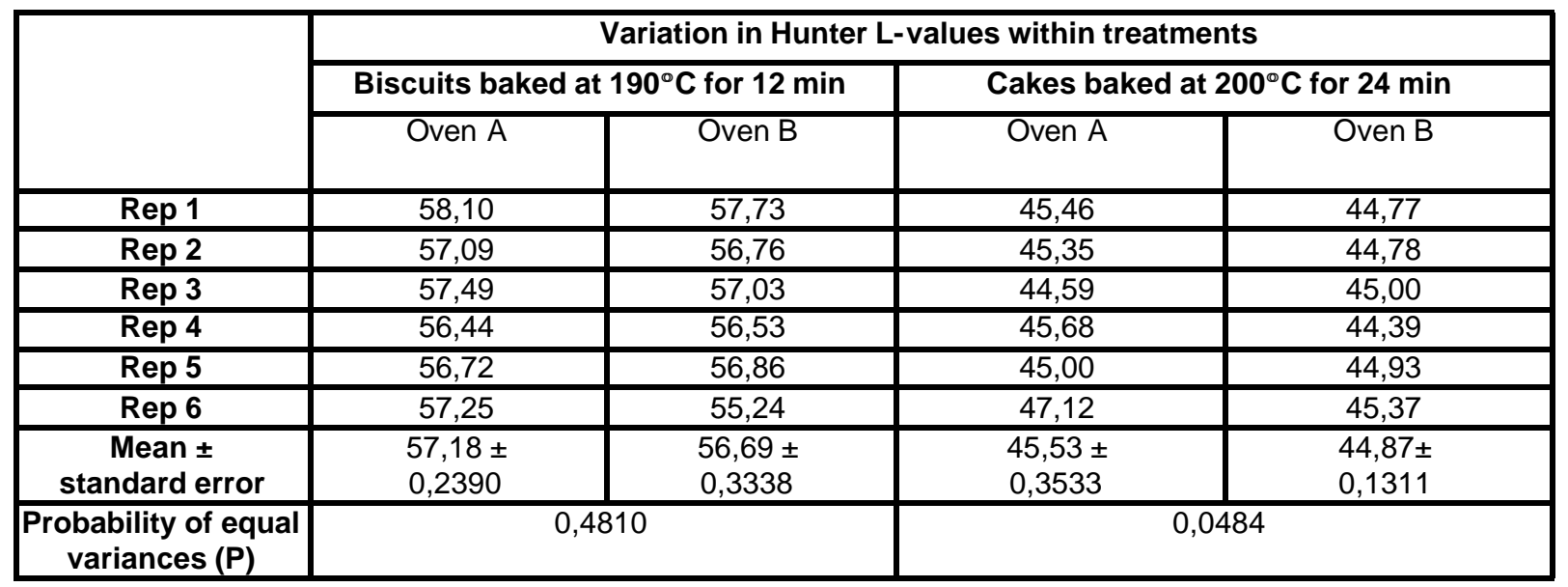

TABLE 7: $\quad$ VARIATION WITHIN TREATMENTS OF TEXTURE IN BISCUITS AND CAKES

\begin{tabular}{|c|c|c|c|c|}
\hline & \multicolumn{4}{|c|}{ Variation in texture $(\mathrm{N})$ within treatments } \\
\hline & \multicolumn{2}{|c|}{ Biscuits baked at $190^{\circ} \mathrm{C}$ for $12 \mathrm{~min}$} & \multicolumn{2}{|c|}{ Cakes baked at $200^{\circ} \mathrm{C}$ for $24 \mathrm{~min}$} \\
\hline & Oven A & Oven B & Oven A & Oven B \\
\hline Rep 1 & 4,00 & 3,87 & 3,42 & 3,50 \\
\hline Rep 2 & 3,97 & 3,83 & 3,54 & 3,37 \\
\hline Rep 3 & 3,73 & 4,00 & 3,42 & 3,43 \\
\hline Rep 4 & 4,19 & 3,79 & 3,30 & 3,43 \\
\hline $\operatorname{Rep} 5$ & 3,63 & 3,42 & 2,85 & 3,37 \\
\hline Rep 6 & 3,80 & 3,89 & 3,25 & 3,39 \\
\hline $\begin{array}{c}\text { Mean } \pm \\
\text { standard error }\end{array}$ & $\begin{array}{l}3,89 \pm \\
0,0846\end{array}$ & $\begin{array}{l}3,80 \pm \\
0,0823\end{array}$ & $\begin{array}{l}3,30 \pm \\
0,0994\end{array}$ & $\begin{array}{l}3,42 \pm \\
0,0200\end{array}$ \\
\hline $\begin{array}{c}\text { Probability of equal vari- } \\
\text { ances }(P)\end{array}$ & \multicolumn{2}{|c|}{0,9529} & \multicolumn{2}{|c|}{0,0031} \\
\hline
\end{tabular}




\section{Statistical analysis}

SAS/STAT® Software, Version 6.2 (SAS Institute, 1996) was used for all statistical analyses. All data were tested for normality prior to analysis of variance.

Differences between treatments Treatments were compared by analysis of variance (ANOVA) and when found to be significantly different $(p 0,05)$, Student's t Least Significant Difference (LSD) tests were performed on the means at the $5 \%$ level of significance. Regression analysis was carried out to establish whether significant trends in the time/ temperature measurements and product characteristics developed after an increase in temperature (Multon, 1996). Regression analysis was carried out separately for Oven A and Oven B, and the resultant intercepts and gradients were compared by means of the Student's t-test. As these were not significantly different $(p 0,05)$, the data for Oven A and Oven B were combined.

Differences within treatments Treatment variances within Oven A and Oven B were compared using Bartlett's test for homogeneity of variances at $190^{\circ} \mathrm{C}$ and $200^{\circ} \mathrm{C}$. This test was carried out to determine the consistency of the CTCS within Oven A and Oven B, from replication to replication (Snedecor \& Cochran, 1989:251-252).

\section{RESULTS AND DISCUSSION}

\section{Differences between treatments}

Time/temperature measurements According to Tables 2 and 3 , there were no significant differences in average oven temperature between Oven $A$ and Oven B, with and without products. For every increase of $1^{\circ} \mathrm{C}$ in the set oven temperature, there was a significant $(p=0,001)$ average oven temperature increase of $0,889^{\circ} \mathrm{C}$ for the biscuits (Figure 3 ), and $0,844^{\circ} \mathrm{C}$ for the cakes (Figure 4). Thus, with and without products, the average oven temperature in Oven A and Oven B is controlled equally effectively by the CTCS.

Moisture loss There were no significant differences in moisture loss between Oven A and Oven B for the biscuits (Table 4). An increase of $1^{\circ} \mathrm{C}$ in the set oven temperature did not cause significantly increased moisture loss in the biscuits. This could be expected from a low-moisture product such as shortbread biscuits (Greenwood \& Munro, 1979:359). The two ovens therefore provided consistent results for biscuits between treatments.

Cakes are a relatively high-moisture product, and there were significant differences in moisture loss between Oven A and Oven B in all treatments, except when the cakes were baked at $200^{\circ} \mathrm{C}$ (Table 4). On average, Oven B showed approximately 0,8 g more moisture loss than Oven A. Although the average oven temperatures were equal, Oven B seems to dis- sipate moisture in a different way, possibly because of the nonwelded plates. The regression of moisture loss at a set oven temperature of $199-202^{\circ} \mathrm{C}$ in Oven $A$ and Oven $B$ when the cakes were baked was significant $(p=0,0001)$. For every increase of $1^{\circ} \mathrm{C}$ in the set oven temperature, there was an average increase in moisture loss of $0,443 \mathrm{~g}$ (Figure 5). The fact that the rate of change is significant indicates that the control system is sensitive to small temperature increments. Moisture loss may be considered a sensitive measurement which is influenced by small differences in temperature.

Height of cakes There were no significant differences in the height of the cakes between Oven A and Oven $B$ in all treatments. The regression in the height of the cakes at a set oven temperature of $199-202^{\circ} \mathrm{C}$ in Oven A and Oven B was not significant ( $p=$ $0,7316)$. This confirms the results of the t-tests and the fact that height measurements are not sensitive to small temperature increments (Walker, 1997).

Colour There were few significant differences in the Hunter L-values between Oven A and Oven B for the biscuits and the cakes. Trends after increase in the set oven temperature are clearly illustrated by regression analysis for Hunter $L$-values. The regression of the Hunter $L$-values at a set oven temperature was significant for the biscuits and the cakes $(p=0,001)$. For every increase of $1^{\circ} \mathrm{C}$ in the set oven temperature, there was an average decrease of 0,780 in the Hunter L-values for the biscuits (Figure 6) and 0,351 for the cakes (Figure 7). The biscuits and cakes therefore became darker in colour because the Maillard reaction is more effective at higher temperatures (Namiki, 1988:116-123). These results indicate that colour is affected by small temperature differences. Colour measurement is therefore an appropriate measurement for this type of research. The differences in the Hunter L-values illustrate their extensive use in food research (Fondroy et al, 1989; Holt et al, 1992; Oliver et al, 1992; McLellan et al, 1995).

Texture There were no significant differences in texture between Oven A and Oven B for the biscuits. The regression of texture at a set oven temperature of $189-192^{\circ} \mathrm{C}$ in Oven A and Oven B for the biscuits was significant $(p=0,0166)$. For every increase of $1^{\circ}$ $C$ in the set oven temperature, there was an average decrease in texture of $0,119 \mathrm{~N}$ (Figure 8), i.e. a significant decrease in hardness. These results may be ascribed to the fact that biscuits expand more at higher temperatures and are more porous and consequently less compact and hard (Charley, 1982:36-38). Note that the mean at $189^{\circ} \mathrm{C}$ is lower than at $190^{\circ} \mathrm{C}$, which may be indicative of a quadratic instead of a linear relationship between texture and temperature.

There were no significant differences in texture between Oven $A$ and Oven $B$ for the cakes. An increase of $1^{\circ} \mathrm{C}$ in temperature from $199-202^{\circ} \mathrm{C}$ therefore has no significant effect on the texture of cakes. This absence of a trend is also illustrated by regression analysis $(p=0,7268)$. Texture is therefore not sensi- 


\section{FIGURE 6: REGRESSION OF HUNTER L-VALUES AT SET OVEN TEMPERATURE FOR BISCUITS} BAKED AT $189-192^{\circ} \mathrm{C}$ 
FIGURE 7: $\quad$ REGRESSION OF HUNTER L-VALUES AT SET OVEN TEMPERATURE FOR CAKES BAKED AT $199-202^{\circ} \mathrm{C}$

The development and testing of a computerised temperature control system in conventional electric ovens 
FIGURE 8: REGRESSION OF TEXTURE AT SET OVEN TEMPERATURE FOR BISCUITS BAKED AT $189-192^{\circ} \mathrm{C}$ 
tive enough for small temperature differences.

\section{Difference within treatments}

Average oven temperature With and without products there were no significant differences in variation in the average oven temperature between Oven $\mathrm{A}$ and Oven $\mathrm{B}$ at $190^{\circ} \mathrm{C}$ and $200^{\circ} \mathrm{C}$.

Moisture loss There were no significant differences in variation in terms of moisture loss in the biscuits or cakes between Oven A and Oven B (Table 5). The range of moisture loss in the biscuits from Oven A was $0,62 \%$ and $0,45 \%$ for the biscuits from Oven B i.e. a difference of $0,17 \%$ between the two ovens. The range of moisture loss in the cakes from Oven $A$ was $1,6 \mathrm{~g}$ and $1,0 \mathrm{~g}$ for the cakes from Oven B. Expressed as percentage moisture loss, this is $0,36 \%$ for Oven $A$ and $0,22 \%$ for Oven B, a difference of $0,14 \%$.

Height of cakes The variation with Oven $A$ and Oven B was similar.

Colour With respect to the biscuits, the extent of the variation in Hunter L-values was the same for Oven A and Oven B (Table 6). There was significantly $(p 0,05)$ more variation in the Hunter $L$-values for the cakes from Oven A. In Oven A the Hunter Lvalues ranged from 45,005 to 47,123 , i.e. a difference of 2,527, and in Oven B the Hunter L-values ranged from 44,398 to 45,374 , i.e. a difference of 1,660 . The significantly higher Hunter L-value obtained during replication six in Oven A $(47,12)$ may be accountable for the significant difference in variation, possibly due to product variability (Little \& Mackinney, 1969).

Texture There was no significant difference in variation in terms of texture between Oven $A$ and Oven B for the biscuits. With respect to the cakes there was significantly more $(p 0,05)$ variation in Oven A (Table 7). In Oven A the texture ranged between $2,8505 \mathrm{~N}$ and $3,5475 \mathrm{~N}$, i.e. a difference of $0,697 \mathrm{~N}$, and in Oven $\mathrm{B}$ the texture ranged from $3,3705 \mathrm{~N}$ to $3,5036 \mathrm{~N}$, i.e. a difference of $0,1331 \mathrm{~N}$. The exceptionally low average value obtained during the fifth replication in Oven A $(2,8505 \mathrm{~N})$ may be responsible for the significant difference in variation for this treatment between Oven A and Oven B.

\section{CONCLUSIONS}

A more sophisticated temperature control system than the capillary thermostat in conventional electric ovens is necessary for laboratory research on foods. The aim of this study was to develop and test the CTCS in two conventional electric ovens to determine whether comparable and consistent results could be obtained for oven and product characteristics in baked products.

With regard to significant differences between and within treatments, Oven A and Oven B did not differ significantly in terms of most oven and product characteristics. Oven A and Oven B therefore did not only provide comparable results, but the CTCS also increased constancy of measurement with replication of treatments. In most cases the regression was linear with regard to selected oven and product characteristics when the set temperature was increased by $1^{\circ} \mathrm{C}$ in Oven $A$ and Oven B. These analysis results illustrate the similarities between Oven A and Oven B as well as the effectiveness of the CTCS, i.e. that an increase of $1^{\circ} \mathrm{C}$ in the set oven temperature has a significant effect on specific oven and product characteristics. The CTCS significantly improves the reproducibility of most quality characteristics of baked products and therefore provides more consistent and repeatable results which, in turn, improves the reliability of the research findings. The CTCS should therefore make a vital contribution to research at food research institutions where conventional electric ovens are used.

All measurements conducted in this study to determine product quality characteristics are valid. The effect of temperature on colour and moisture loss is well illustrated by these measurements and may therefore be considered suitable measurements for this type of study. However, height and texture measurements did not provide as clear an indication of the effect of small temperature variations during the baking process.

\section{REFERENCES}

AACC (1983): Approved methods of the American Association of Cereal Chemists. 8th ed. St. Paul, MN.

BAKER, BA, DAVIS, EA \& GORDON, J (1990): Glass and metal pans for use with microwave and conventionally heated cakes. Cereal Chem 67(5):448-451.

BALTSAVIAS, A, JURGENS, A \& VAN VLIET, T (1997):

Factors affecting fracture properties of short-dough biscuits. J Texture Stud 28 (2):205-219.

BOURNE, MC (1982): Food texture and viscosity. Concept and measurement. New York. Academic Press.

CHARLEY, H (1982): Food science. 2nd ed. New York. Macmillan.

DE VRIES, U, VELTHUIS, H \& KOSTER, K (1994): Baking ovens and product quality - a computer model. Food Sci Technol Today 9(4):232-234.

DORF, RC (1986): Modern control systems. 4th ed. Reading. Addison-Wesley.

FAHLOUL, D, TRYSTRAM, G, DUQUENOY, A \& BARBOTTEAU, I (1994): Modelling heat and mass transfer in band oven biscuit baking. Lebensmittel-Wissenschaft-undTechnologie 27(2):119-124.

FONDROY, EB, WHITE, PJ \& PRUSA, KJ (1989): Physical and sensory evaluation of lean white cakes containing substituted fluffy cellulose. Cereal Chem 66(4):402-404.

GARRISON, CL \& PEART, MV (1986): Effect of radiant heat transfer: cake baking in a conventional electric residential oven. Home Econ Res J 14(3):336-341.

GREENWOOD, CT \& MUNRO, DN (1979): Cereals, roots and other starch-based product, in Priestly, RJ (ed). Effects of heating on foodstuffs. London. Applied Science Publishers.

HOLT, SD, McWATTERS, KH \& RESURRECCION, AVA

(1992): Validation of predicted baking performance of muffins containing mixtures of wheat, cowpea, peanut, sorghum and cassava flours. J Food Sci 57(2):470-474.

KILBORN, RH \& TIPPLES, KH (1981): Heat sink reference oven. Cereal Chem 58(4):295-299.

LITTLE, AC \& MACKINNEY, G (1969): The sample as a problem. Food Technol 23(1):25-28

MARIS, PIW, WHEELER, RJ \& THACKER, D (1995): Turn- 
ing up the heat. Food Manuf 70(9):27-28.

McLELLAN, MR, LIND, LR \& KIME, RW (1995): Hue angle determinations and statistical analysis for multiquadrant Hunter L-, a-, b-data. J Food Qual 18(3):235-240.

MULLER, M (1992): Control of oven temperature with and without the Unitemp temperature controller. Research report. Department of Consumer Studies, University of Stellenbosch.

MULTON, JL (1996): General principles of practical metrology, in Multon, JL (ed). Quality control for foods and agricultural products. New York. VCH Publishers.

NAMIKI, M (1988): Chemistry of Maillard reactions: recent studies on the browning reaction mechanism and the development of antioxidants and mutagens. Advances in food research. Vol 32. New York. Academic Press.

OLIVER, JR, BLAKENEY, AB \& ALLEN, HM (1992): Measurement of flour colour in colour space parameters. Cereal Chem 69(5):546-551.

PEART, MV, KERN, ST \& DE WITT, DP (1980): Optimising oven radiant energy use. Home Econ Res J 8(4):242-251. POMERANZ, Y \& MELOAN, CE (1987): Food analysis: theory and practice. 2nd ed. New York. Van Nostrand Reinold.

SAS Institute (1996): SAS/STAT® Software. SAS Institute. Cary, NC.
SHELKE, K, FAUBION, JM \& HOSENEY, RC (1990): The dynamics of cake baking as studied by a combination of viscometry and electrical resistance oven heating. Cereal Chem 67(6):575-580.

SNEDECOR, GW \& COCHRAN, WG (1989): Statistical methods. 8th ed. lowa. lowa State University Press.

SOBCZYNSKA, D \& SETSER, CS (1991): Replacement of shortening by maltodextrin emulsifier combinations in chocolate layer cakes. Cereal Foods World 36(12):1017-1026.

SABS (1997): Standard Specification 153 for electric stoves, cooking tops, ovens, grills and similar appliances. 3rd ed.

Pretoria. South African Bureau of Standards.

SWAIN, MJ, RUSSEL, SL \& SWAIN, MVL (1997): Design and development of a microwave oven with reproducible performance for food tests. Proceedings of the 6th International Microwave and High Frequency Heating Conference, Italy. September:326-329.

VILJOEN, DL, MULLER, M, \& SADIE, A (1995): The effect of the Unitemp Temperature Controller on temperature control in household electric ovens used for food research purposes. J of Dietetics and Home Econ 23(3):149-156.

WALKER, CE (1997): Personal communication. Kansas State University. Manhattan, Kan. 